\author{
Research Article \\ https://doi.org/10.53803/turvehab.990370
}

\title{
Effects of Temperature, Light and Salinity on Germination of Salsola crassa (Amaranthaceae) Seeds from Different Years
}

\author{
İnci Bahar Çınar (iD) 1,*, Gül Ayyıldız (iD)2, Ahmet Emre Yaprak (iD)2, Gül Nilhan Tuğ (iD)2 \\ ${ }^{1}$ Department of Environmental Protection and Technologies, Suluova Vocational School, Amasya University, \\ TR-05500, Amasya, Turkey \\ ${ }^{2}$ Department of Biology, Faculty of Science, Ankara University, TR-06100, Ankara, Turkey \\ *Correspondence: İnci Bahar Çınar, inci.cinar@amasya.edu.tr
}

\begin{tabular}{lll}
\hline Received: 02.09.2021 & Accepted: 17.10.2021 & Published Online: 31.12 .2021 \\
\hline
\end{tabular}

\begin{abstract}
Salsola crassa is a halophytic plant species from the Amaranthaceae family. In this study we aimed to find out the effect of temperature, light, salinity, and age of seeds on germination ability of $S$. crassa. Seeds of the species were collected in 2013 and 2014, and seed wings which are known as perianth segments, were removed before the experiments. Both seeds from different years were germinated under the same conditions. Two temperature regimes at $5^{\circ} \mathrm{C} / 16^{\circ} \mathrm{C}$ and $8^{\circ} \mathrm{C} / 20^{\circ} \mathrm{C}$ were used under dark and daily photoperiodism at $12 \mathrm{~h}$ intervals for determination of the effects of temperature. Seeds were germinated under different $\mathrm{NaCl}$ concentrations. Seeds that did not germinate under saline conditions were taken into recovery and the viability of the seeds that did not germinate after recovery were tested with the Triphenyl Tetrazolium Chloride (TTC) test. As a result, photoperiodism positively influenced the germination rate $(\mathrm{p}<0.05)$ of seeds from both years. Even though an increase in salinity decreased the germination rate it can be said that $S$. crassa is an euhalophyte whose seeds can even germinate at $1800 \mathrm{mM} \mathrm{NaCl}$. Although the age of seeds is an important parameter for seed germinability, there was not any statistically significant difference between the seed viability and final germination rates for the S. crassa seeds from 2013 and 2014.
\end{abstract}

Keywords: Amaranthaceae, germination, halophyte, salinity, Salsola crassa

\section{Farklı Yıllara Ait Salsola crassa (Amaranthaceae) Tohumlarının Çimlenmesi Üzerine Sıcaklık, Işık ve Tuzluluğun Etkileri}

\begin{abstract}
Özet
Salsola crassa, Amaranthaceae familyasından halofit bir bitkidir. Çalışmanın amacı; farklı yıllara ait S. crassa tohumlarının çimlenmesi üzerine sıcaklık, ışık, tuzluluk ve tohum yaşının etkilerinin belirlenmesidir. Bu çalışmada kullanılan tohumlar, 2013 ve 2014 yıllarında toplanmıştır ve deneysel çalışmalara başlanmadan önce periant segmentleri uzaklaştırılmıștır. Farklı yıllarda toplanmış olan bütün tohumlar aynı koşullar altında çimlendirilmiştir. Sicaklık denemeleri için $(12 \mathrm{~s} / 12 \mathrm{~s}) 5^{\circ} \mathrm{C} / 16^{\circ} \mathrm{C}$ ve $8^{\circ} \mathrm{C} / 20^{\circ} \mathrm{C}$ olmak üzere iki farklı sıcaklık kullanılmıştır. Tohumlar farklı $\mathrm{NaCl}$ konsantrasyonlarında çimlendirilmiş ve çimlenmeyen tohumlar iyileștirilmeye alınmıștır. İyileștirme sonucunda çimlenmeyen tohumların canlılıkları TTC testi ile belirlenmiştir. Sonuç olarak; fotoperiyodizm uygulamasının daimi karanlıkla karşılaştırıldığında tohum çimlenmesi üzerinde olumlu etki yarattığı gözlenmiștir $(\mathrm{p}<0.05)$. Artan tuz konsantrasyonunun her iki yıla ait tohumların çimlenmesini kademeli olarak baskıladığı belirlenmiş olsa da $S$. crassa türünün $1800 \mathrm{mM} \mathrm{NaCl}$ çözeltisinde bile çimlenme özelliğine sahip olması, türün öhalofit olduğunu göstermektedir. Tohum yaşının tohum çimlenmesinde önemli bir parametre olduğunun bilinmesine karşın, $S$. crassa tohumlarında yapılan çalışmadaki bir yıllık farkın
\end{abstract}

Suggested Citation:

Çınar, İ.B., Ayyıldız, G., Yaprak, A.E. \& Tuğ, G.N. (2021). Effects of Temperature, Light and Salinity on Germination of Salsola crassa (Amaranthaceae) Seeds from Different Years. Türler ve Habitatlar 2(2): 98-112. 
tohum canlılığı ve son çimlenme yüzdeleri bakımından istatistiksel olarak önemli bir fark yaratmadığı bulunmuştur.

Anahtar kelimeler: Amaranthaceae, çimlenme, halofit, Salsola crassa, tuzluluk

\section{INTRODUCTION}

Halophytes receive more attention every day because of their ability to survive under saline conditions and because of an increase in soil salinity in agricultural areas. Soil salinity becomes a major problem, especially in arid and semi-arid areas and is mainly caused by high evaporation, deficiencies of precipitation as a result of human related global climate change and wrong irrigation procedures (Greenway \& Munns 1980), which increase the importance of halophytes and understanding of their biology and results in many studies, especially about their germination ecology (Mariko et al. 1992; Khan et al. 2002; Parsons 2012; Estrelles et al. 2015; Rasheed et al. 2019).

Halophytes have special adaptations for germination at high osmotic pressure because of high salinity and complete their life cycles under saline conditions where other plants cannot germinate and survive ( Gul et al. 2013; Estrelles et al. 2015). However, studies on their germination reveal that they show better germination at slightly saline or non-saline conditions (Ungar 1978; Huiskes et al. 1985; Khan \& Ungar 1997; Baskin CC \& Baskin JM 1998; Khan \& Gul 1998; Khan et al. 2004; Sekmen et al. 2004; Wang et al. 2008). Even though salinity can decrease germination percentage, inhibit, or retard germination, when the soil salinity decreases after seasonal precipitation these seeds can recover and germinate (Woodell 1985; Ungar 1995; Khan et al. 2002; Wei et al. 2008).

Salsola crassa M.Bieb. is an annual species from the Amaranthaceae family distributed over saline areas (Figure 1). The genus Salsola L. has species that are adapted to saline and semi-saline areas, and their seeds have wings or perianth remnants that inhibit or retard the germination process physically or chemically (Aiazzi \& Arguello 1992; Wei et al. 2008; Wang et al. 2013). Takeno \& Yamaguchi (1991) stated that seed wings of S. komarovii Iljin contained ABA a germination inhibitor.

It was stated that many Salsola species have salinity tolerance at the germination stage of their life cycles: S. kali L. (Woodell 1985), S. baryosma (Schult.) Dandy (Mohammad \& Sen 1990), S. villosa Schult (Assaeed 2001), S. iberica Sennen \& Pau (Khan et al. 2002), S. imbricata Forssk. (El-Keblawy et al. 2007; Mehrun-Nisa 2007), S. affinis C.A.Mey. ex Schrenk (Wei et al. 2008), S. vermiculata L. (Guma et al. 2010), S. ferganica Drobow (Wang et al. 2013), S. grandis Freitag, Vural \& N.Adıgüzel (Cınar et al. 2016).

Seed age is also an important parameter for germination percentages and rates. Although many studies indicated that aging generally decreased the germination rates and percentages (Rees \& Long 1993; Tielbörger \& Valleriani 2005; Rojas-Aréchiga \& VázquezYanes 2000; Flores et al. 2005), some of them mentioned that in some species seed germination tended to increase with age (Mandujano et al. 1997; 2005; Bowers 2000; Shimomura et al. 2000; Rojas-Aréchiga et al. 2001; De la Barrera \& Nobel 2003; Flores et al. 2005). In some cases, one-year old seeds did not differ from fresh ones for germination behavior (Ruedas et al. 2000). 
The authors aimed to determine the germination characteristics of Salsola crassa under different light, temperature, and salinity conditions and to find out whether waiting before experiments at laboratory conditions caused any change in germination ability.

\section{MATERIAL AND METHOD}

Seeds of Salsola crassa were collected from Bolluk Lake (Cihanbeyli/Konya) in 2013 and 2014 and kept at $+4^{\circ} \mathrm{C}$ until the germination experiments were started in 2015. Also, seed wings were removed to avoid an inhibitory effect (Figure 2).

To prevent fungal infection, the seeds were treated with $0.1 \%$ sodium hypochlorite solution for 3 minutes and then washed three times with sterile distilled water. Then 4 replicates of 25 seeds for each year were placed in petri dishes on two layers of Whatman No.1 filter paper moistened with $4 \mathrm{ml}$ distilled water. The petri dishes were sealed with parafilm and then they were incubated at daily $(12 / 12 \mathrm{~h})$ temperatures of $5 / 16^{\circ} \mathrm{C}$ and $8 / 20^{\circ} \mathrm{C}$ in light (12 h daily photoperiod) and in continuous dark (petri dishes were kept in black bags) for 14 days. Germination was checked every 2 days for the light trial and was checked at the end of the trial for the dark trial germination. These temperatures are the mean max and min daily temperatures of the distribution area during the germination period (April and May). The emergence of radicle was considered as germination. The rate of germination in light was calculated by using the modified Timson index of germination velocity (Khan \& Ungar 1997).

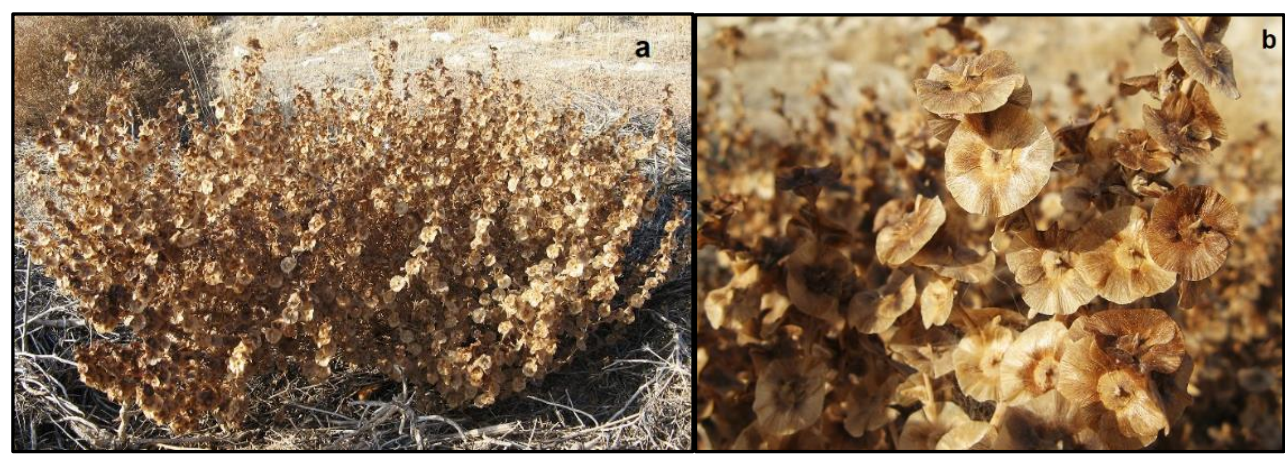

Figure 1. Habitus (a) and winged fruits (b) of Salsola crassa.

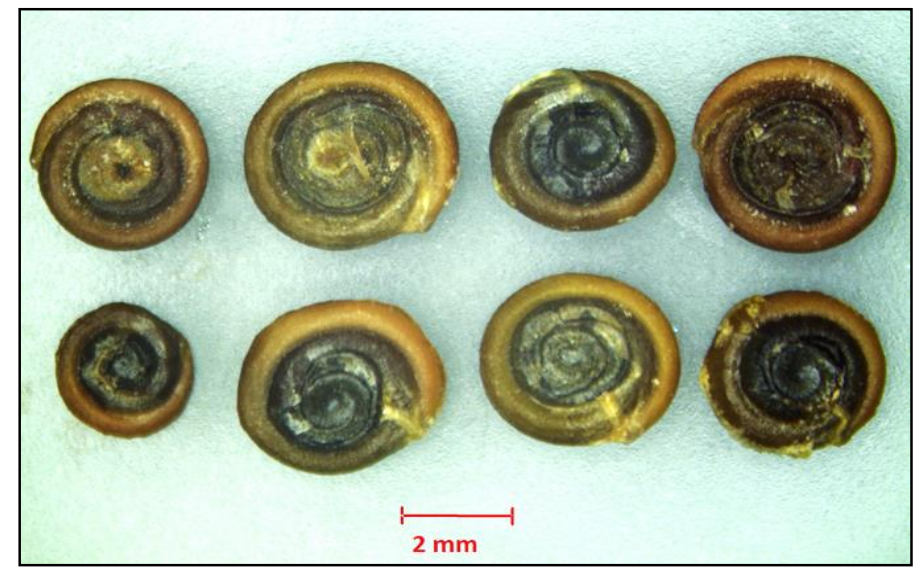

Figure 2. Salsola crassa seeds. 
Twenty-five seeds with 4 replicates from each year were incubated at optimum light and temperatures for 14 days at the following $\mathrm{NaCl}$ concentrations: distilled water, 100, 200, 300, $400,500,600,800,1000,1200,1400,1600$ and $1800 \mathrm{mM} \mathrm{NaCl}$ solutions. Seeds that failed to germinate during the salinity trials were washed using distilled water and then were incubated at optimum temperature for another 14 days with $4 \mathrm{ml}$ of distilled water. The viability of the non-germinated seeds was determined with the TTC test (Baskin CC \& Baskin JM 1998).

The germination index was calculated with the formula: $\Sigma \mathrm{G} / \mathrm{t}$ where $\mathrm{G}$ is the seed germination percentage at 2-day intervals and $t$ is the total germination period. The max value obtained with this equation is 50 and indicates a high germination velocity (Khan \& Ungar 1984).

Recovery percentage was calculated with the formula: $[(a-b) /(c-b)] \times 100$ here a: total number of germinated seeds tested (all the seeds germinated in $\mathrm{NaCl}$ treatment and germinated after recovery); b: number of seeds germinated under saline conditions; c: total number of seeds tested (Gul \& Weber 1999). The last germination was calculated with the formula: (a / c) $\times 100$ (Baskin CC \& Baskin JM, 1998). Seed viability was calculated with the formula: $[(a+d) / c] \times 100$. Here $d$ is the number of embryos that were stained pink in the TTC solution (Baskin CC \& Baskin JM 1998).

Ungerminated seeds were treated with a $1 \%$ tetrazolium solution for 24 hours at $30^{\circ} \mathrm{C}$. Afterwards, the seeds' viability was observed under a binocular microscope (Grabe 1970; Williams 2001). Red staining of the seed was considered a positive indicator of viability as it indirectly detected the respiratory activity at the cellular level. Contrarily, TTC does not react with non-viable seeds and as a result, they do not stain (França-Neto \& Krzyzanowski 2019).

Decreasing germination percentage (DGP) was calculated according to Zhang et al. 2015; DGP $=[($ germination $\%$ at distilled water-germination $\%$ at salinity $) /$ germination $\%$ at distilled water] $\times 100$.

All data were arcsin transformed and then analyzed with the SPSS 25.0 and the Analysis of Variance (ANOVA) was used for the determination of influences of the trials. Significance controls were made with the $T$ test $(p<0.05)$. The paired sample $t$ test (SPSS 25.0) was used for the comparison of germination characteristics of the seeds from different years.

\section{RESULTS AND DISCUSSION}

Germination percentage of 2013 and 2014 seeds at $5^{\circ} \mathrm{C} / 16^{\circ} \mathrm{C}$ and $12 \mathrm{~h} / 12 \mathrm{~h}$ photoperiodism were found to be $64 \%$ and $97 \%$, respectively, and for the dark trial $55 \%$ for 2013 and $89 \%$ for 2014. The germination percentage was $85 \%$ for 2013 and $100 \%$ for 2014 for the $8^{\circ} \mathrm{C} / 20^{\circ} \mathrm{C}$ and 12h/12h photoperiodism, and for darkness $60 \%$ for 2013 and $95 \%$ for 2014 .

As in all plants, distribution and germination ability of halophytes are mainly determined by temperature and water availability (Baskin CC \& Baskin JM 1998). According to the germination studies on the Salsola species, different species of Salsola have their own germination temperatures (El-Keblawy et al. 2007; Wei et al. 2008; Guma et al. 2010). Terzi et al. (2017) used 6 fixed temperatures $\left(10^{\circ} \mathrm{C}, 15^{\circ} \mathrm{C}, 20^{\circ} \mathrm{C}, 25^{\circ} \mathrm{C}, 30^{\circ} \mathrm{C}\right.$ and $\left.35^{\circ} \mathrm{C}\right)$ in their work on $S$. crassa, and found out that the highest germination occurs at $20^{\circ} \mathrm{C}$ and $25^{\circ} \mathrm{C}$, and there was an obvious decrease at $10^{\circ} \mathrm{C}, 15^{\circ} \mathrm{C}$ and $35^{\circ} \mathrm{C}$. In this study, two temperature 
regimes were used, which were determined according to the mean day and night temperatures of the germination season of the distribution areas. For 2013 seeds, there was a statistically significant difference for the temperature regimes $(\mathrm{F}=8.342, \mathrm{p}<0.05)$ but for 2014 there was no statistically significant difference $(\mathrm{F}=1.000, \mathrm{p}>0.05)$ (One Way ANOVA, SPSS 25.0). According to these results, it can be concluded that prolonged storage period narrows the germination preference temperature range of $S$. crassa seeds. For the seeds of both years, the $8^{\circ} \mathrm{C} / 20^{\circ} \mathrm{C}$ and $12 \mathrm{~h}$ photoperiodism resulted in higher germination. For both the temperature regimes, the better results were observed at $12 \mathrm{~h}$ photoperiodism other than complete darkness, due to this result and for the control of germination experiments, the $8^{\circ} \mathrm{C} / 20^{\circ} \mathrm{C}$ and $12 \mathrm{~h}$ photoperiodism were used for the determination of the influence of salinity on germination.

All the results about effects of salinity on germination, recovery ratios, viability test results, decreasing germination percentage values have been given in Table 1 for 2013 and in Table 2 for 2014. Comparisons of germination percentages for 2013 and 2014 have been given in Figure 3.

Table 1. Germination response of 2013 seeds to different $\mathrm{NaCl}$ concentrations.

\begin{tabular}{|l|c|c|c|c|c|c|}
\hline Salsola crassa & $\begin{array}{c}\text { Germination } \\
\text { percentage }\end{array}$ & $\begin{array}{c}\text { Germination } \\
\text { rate }\end{array}$ & $\begin{array}{c}\text { Recovery } \\
\text { percentage }\end{array}$ & $\begin{array}{c}\text { Last germination } \\
(\boldsymbol{\%})\end{array}$ & $\begin{array}{c}\text { Viability } \\
(\boldsymbol{\%})\end{array}$ & DGP \\
\hline Distilled water & $85^{\mathrm{a}}$ & 29.57 & - & 85 & 85 & - \\
\hline $\mathbf{1 0 0} \mathbf{~ m M ~ N a C l}$ & $55^{\mathrm{b}}$ & 16.36 & 80 & 91 & 97 & 35.29 \\
\hline $\mathbf{2 0 0} \mathbf{~ m M ~ N a C l}$ & $48^{\mathrm{b}}$ & 14.5 & 69.23 & 84 & 93 & 43.53 \\
\hline $\mathbf{3 0 0} \mathbf{~ m M ~ N a C l}$ & $49^{\mathrm{b}}$ & 14.71 & 76.47 & 88 & 95 & 42.35 \\
\hline $\mathbf{4 0 0} \mathbf{~ m M ~ N a C l}$ & $47^{\mathrm{b}}$ & 14 & 81.13 & 90 & 97 & 44.70 \\
\hline $\mathbf{5 0 0} \mathbf{~ m M ~ N a C l}$ & $37^{\mathrm{b}}$ & 9.93 & 69.84 & 81 & 91 & 56.47 \\
\hline $\mathbf{6 0 0} \mathbf{~ m M ~ N a C l}$ & $43^{\mathrm{b}}$ & 12.07 & 77.19 & 87 & 94 & 49.41 \\
\hline $\mathbf{8 0 0} \mathbf{~ m M ~ N a C l}$ & $33^{\mathrm{bc}}$ & 10.28 & 85.07 & 90 & 97 & 61.14 \\
\hline $\mathbf{1 0 0 0} \mathbf{~ m M ~ N a C l}$ & $32^{\mathrm{bc}}$ & 9.5 & 76.47 & 84 & 92 & 62.35 \\
\hline $\mathbf{1 2 0 0} \mathbf{~ m M ~ N a C l}$ & $19^{\text {cd }}$ & 4.57 & 83.95 & 87 & 88 & 77.64 \\
\hline $\mathbf{1 4 0 0} \mathbf{~ m M ~ N a C l}$ & $17^{\text {cd }}$ & 4.57 & 61.44 & 68 & 76 & 80 \\
\hline $\mathbf{1 6 0 0} \mathbf{~ m M ~ N a C l}$ & $10^{\mathrm{d}}$ & 2.35 & 56.66 & 61 & 83 & 88 \\
\hline $\mathbf{1 8 0 0} \mathbf{~ m M ~ N a C l}$ & $7^{\mathrm{d}}$ & 1.57 & 52.68 & 56 & 66 & 91.76 \\
\hline
\end{tabular}

Table 2. Germination response of 2014 seeds to different $\mathrm{NaCl}$ concentrations.

\begin{tabular}{|l|c|c|c|c|c|c|}
\hline Salsola crassa & $\begin{array}{c}\text { Germination } \\
\text { percentage }\end{array}$ & $\begin{array}{c}\text { Germination } \\
\text { rate }\end{array}$ & $\begin{array}{c}\text { Recovery } \\
\text { percentage }\end{array}$ & $\begin{array}{c}\text { Last germination } \\
(\boldsymbol{\%})\end{array}$ & $\begin{array}{c}\text { Viability } \\
(\boldsymbol{\%})\end{array}$ & DGP \\
\hline Distilled water & $100^{\mathrm{a}}$ & 39.50 & - & 100 & 100 & - \\
\hline $\mathbf{1 0 0} \mathbf{~ m M ~ N a C l}$ & $94^{\mathrm{b}}$ & 30.78 & 33.33 & 96 & 96 & 6 \\
\hline $\mathbf{2 0 0} \mathbf{~ m M ~ N a C l}$ & $94^{\mathrm{b}}$ & 31.14 & 50 & 97 & 98 & 6 \\
\hline $\mathbf{3 0 0} \mathbf{~ m M ~ N a C l}$ & $75^{\mathrm{c}}$ & 28.21 & 84 & 96 & 96 & 25 \\
\hline $\mathbf{4 0 0} \mathbf{~ m M ~ N a C l}$ & $69^{\text {cd }}$ & 25.93 & 67.74 & 90 & 90 & 31 \\
\hline $\mathbf{5 0 0} \mathbf{~ m M ~ N a C l}$ & $60^{\text {cd }}$ & 20.78 & 70 & 88 & 88 & 40 \\
\hline $\mathbf{6 0 0} \mathbf{~ m M ~ N a C l}$ & $55^{\mathrm{d}}$ & 17.21 & 77.78 & 90 & 90 & 45 \\
\hline $\mathbf{8 0 0} \mathbf{~ m M ~ N a C l}$ & $41^{\mathrm{e}}$ & 13.93 & 54.24 & 73 & 75 & 59 \\
\hline $\mathbf{1 0 0 0} \mathbf{~ m M ~ N a C l}$ & $31^{\mathrm{e}}$ & 10.21 & 55.07 & 69 & 71 & 69 \\
\hline $\mathbf{1 2 0 0} \mathbf{~ m M ~ N a C l}$ & $8^{\mathrm{f}}$ & 2.78 & 60.87 & 64 & 67 & 92 \\
\hline $\mathbf{1 4 0 0} \mathbf{~ m M ~ N a C l}$ & $7^{\mathrm{f}}$ & 2.5 & 52.68 & 56 & 60 & 93 \\
\hline $\mathbf{1 6 0 0} \mathbf{~ m M ~ N a C l}$ & $8^{\mathrm{f}}$ & 1.64 & 63.04 & 58 & 59 & 92 \\
\hline $\mathbf{1 8 0 0} \mathbf{~ m M ~ N a C l}$ & $5^{\mathrm{f}}$ & 1.64 & 61.05 & 63 & 68 & 95 \\
\hline
\end{tabular}




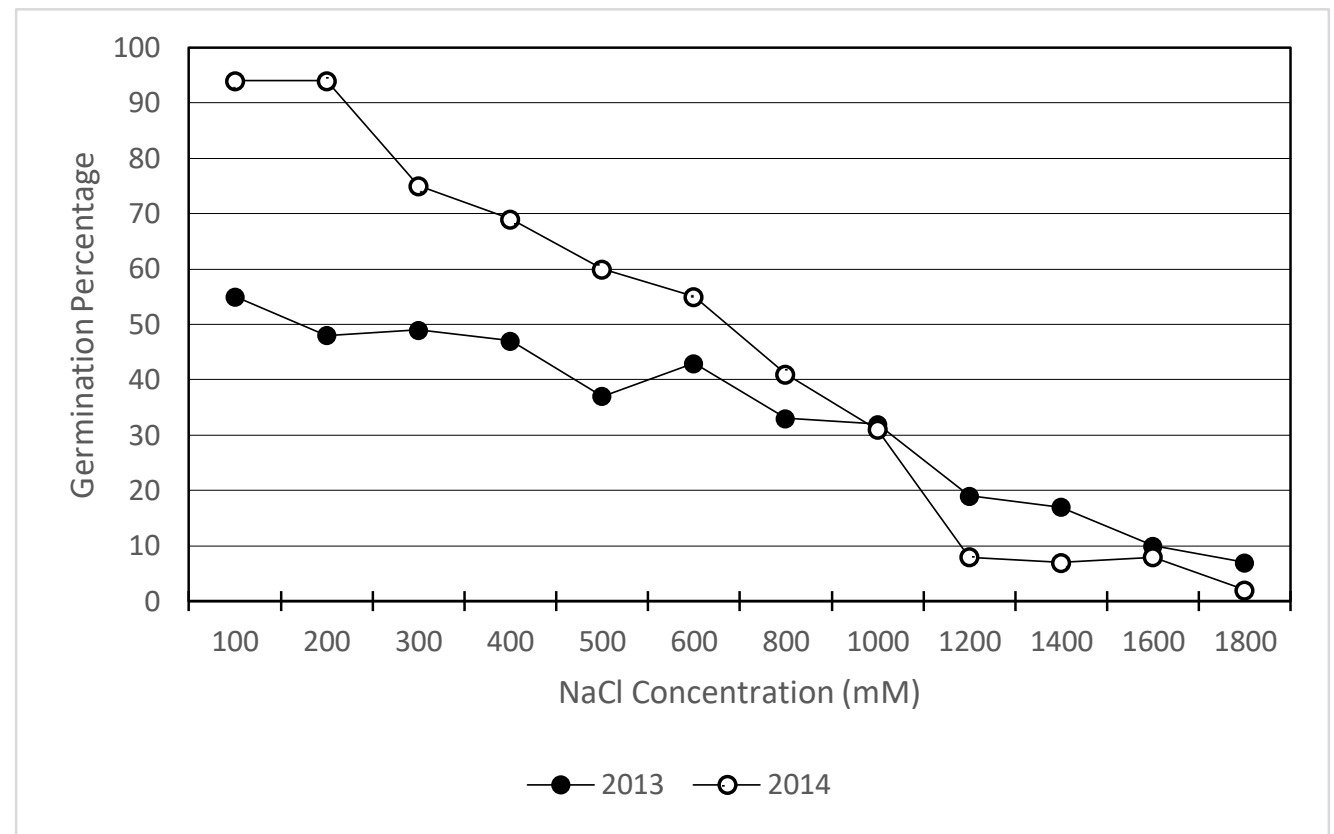

Figure 3. Comparison of the results of germination percentages at different salt concentrations for 2013 and 2014 seeds.

Halophytes, like glycophytes, germinate better in non-saline conditions (Seneca 1969; Onnis \& Bellettato 1972; Breen et al. 1977; Dietert \& Shontz 1978; Ungar 1978; Huiskes et al. 1985; Khan \& Ungar 1997; Baskin CC \& Baskin JM 1998; Khan \& Gul 1998; Khan et al. 2004; Sekmen et al. 2004; Wang et al. 2008; Terzi et al. 2017). For both the seeds from different years, better germination percentages were observed in distilled water and an increase in salinity decreased the germination percentages (Figure 3, Tables 1 and 2).

Salinity tolerance of some species both defines their habitat types and distribution (Soriano et al. 2014). Germination is generally the most fragile period of a plants' life cycle and defines the soil conditions confronted by the plant (Ungar 1982). Factors like salinity, temperature and photoperiodism and their interactions influenced the timing and place of germination (Rasheed et al. 2019).

According to the results of Yildiztugay et al. (2014) the seedling phase of the euhalophyte Salsola crassa can tolerate high salinity levels, even at $1500 \mathrm{mM} \mathrm{NaCl}$. Also, the results of Terzi et al. (2017) showed that this species can germinate at $800 \mathrm{mM} \mathrm{NaCl}$. Although the germination percentage decreased as the salinity concentration increased, $S$. crassa seeds were successful in our trials in germinating even at the concentration of 1800 $\mathrm{mM} \mathrm{NaCl}$.

There was a statistically significant difference between the responses of the 2013 seeds to changing $\mathrm{NaCl}$ concentrations $(\mathrm{F}=10.147, \mathrm{p}<0.05)$, which is also true for the 2014 seeds $(\mathrm{F}=102.867, \mathrm{p}<0.05)$ (Duncan post-hoc, SPSS 25.0).

Germination percentages and rates decreased with increasing $\mathrm{NaCl}$ concentrations for both years (Tables 1 and 2). Even though they both showed a decrease, it was not statistically significant and showed the same pattern up to $1000 \mathrm{mM} \mathrm{NaCl}$. At this point the 2014 seeds showed a higher decrease in germination percentage (Table 3). There is a negative correlation between increasing salinity and both the last germination percentage and seed viability. The 
2014 seeds had a higher ratio of non-viable seeds, and this could be caused by the waiting period before the start of experiments. Seed viability also showed a decrease at higher salinities, but interestingly the 2013 older seeds showed a higher viability ratio than 2014 seeds. This can be caused by the Reactive Oxygen Species (ROS), Abscisic Acid (ABA) or Gibberellic Acid (GA) content of the seeds (Gomes \& Garcia 2013, Atia et al. 2009, Yuan et al. 2011). In conclusion, there should be more detailed studies focused on the physiology of the older seeds.

Zhang et al. (2015) formulated the decreasing germination percentage and investigated the germination behavior of 12 halophytes and concluded that the highest decreasing germination percentage means the lowest salt tolerance. The findings of this study also confirmed that decreasing salt tolerance with increasing salinity, even though with high decreasing germination percentages, there are still some seeds that can tolerate $1800 \mathrm{mM}$ $\mathrm{NaCl}$ (Tables 1 and 2, Figure 4), so Salsola crassa is an euhalophyte species.

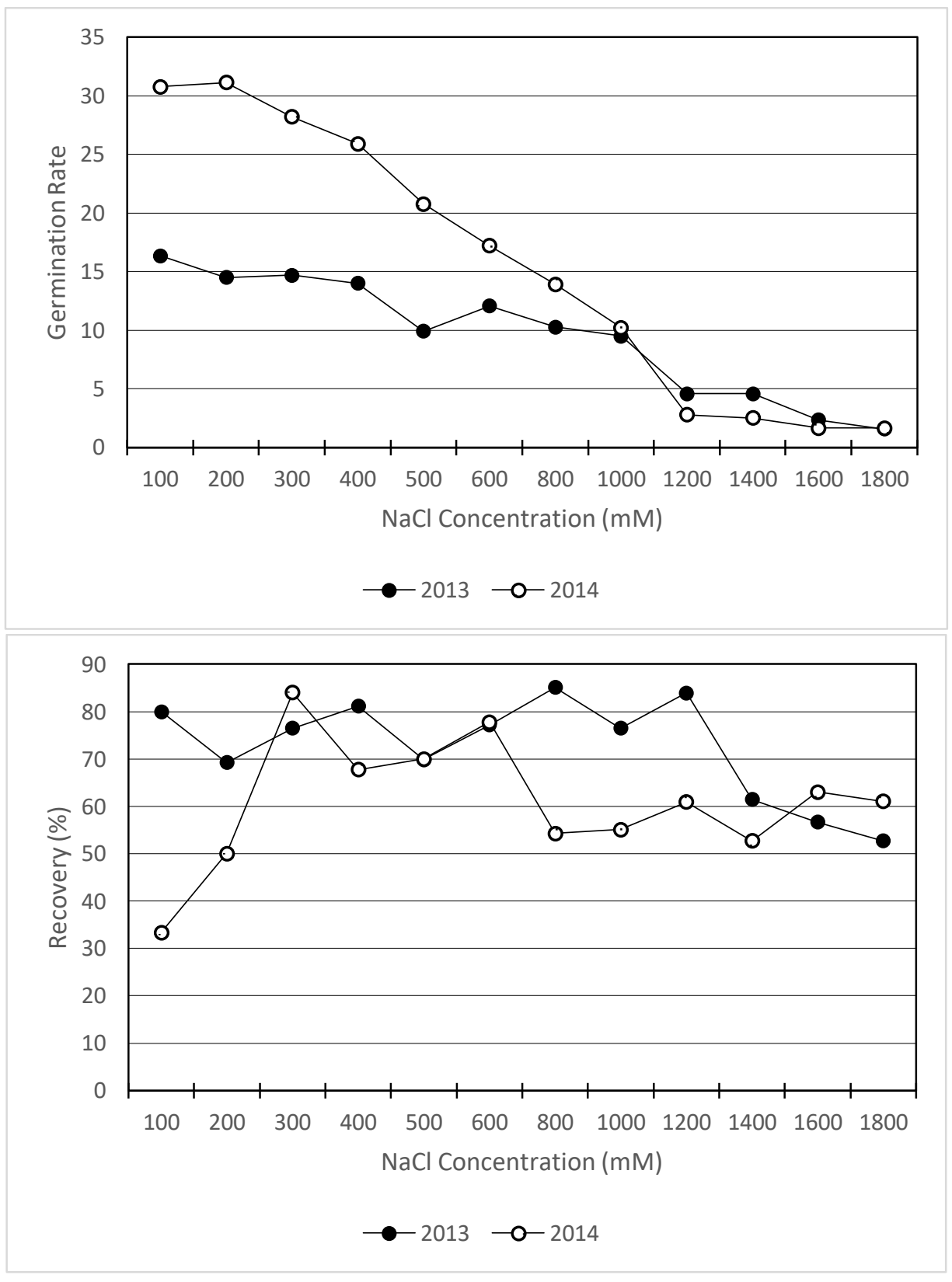



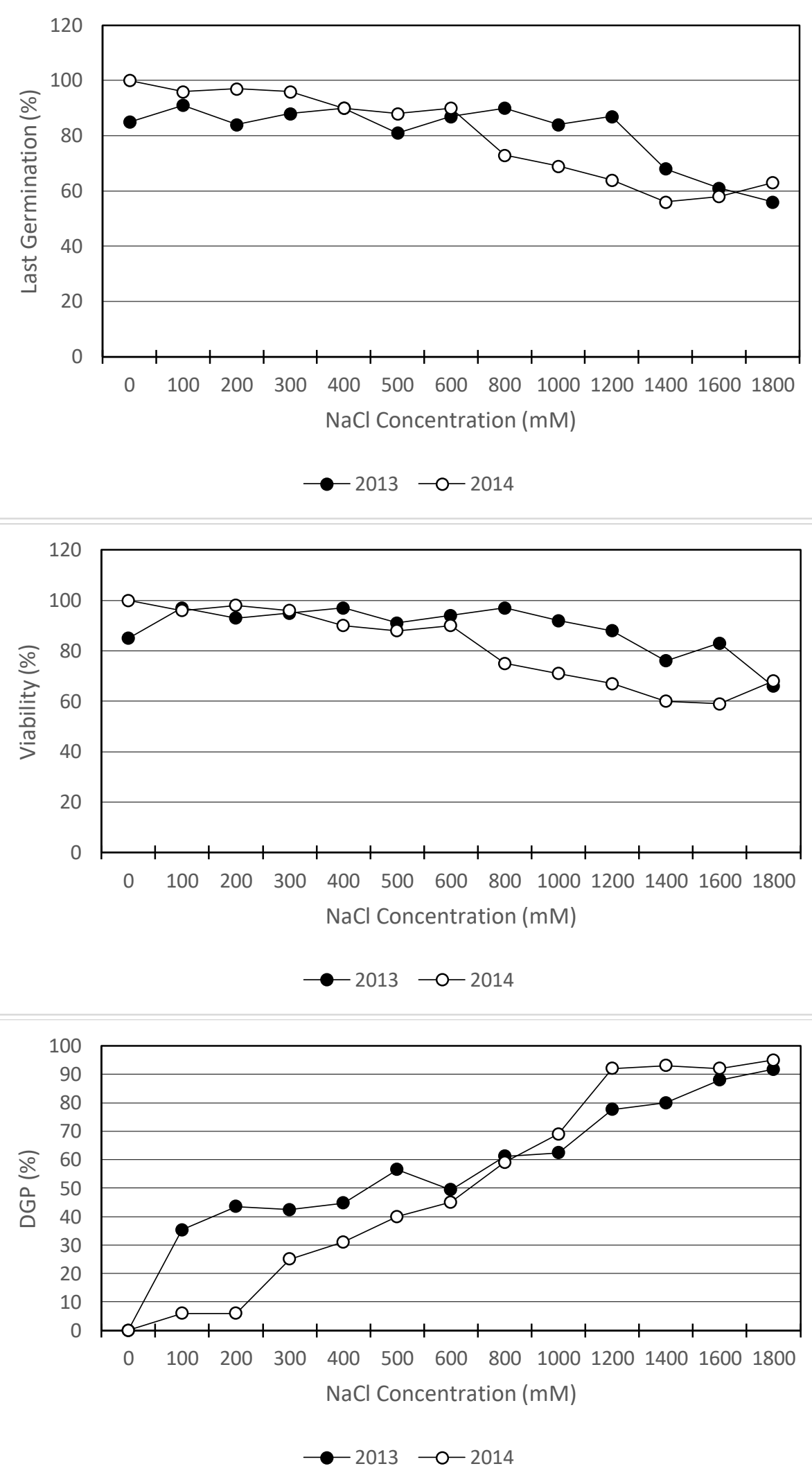

Figure 4. Comparison of the results of germination rate, recovery $\%$, last germination $\%$, viability $\%$ and DGP at different salt concentrations for 2013 and 2014. 
There is a statistically significant difference between the germination percentages, germination rates and recovery rates values of the seeds for 2013 and $2014(p<0.05)$ (Table 3). But there is no statistically significant difference for the last germination percentages and seed viability ratio ( $p>0.05$ ) (Paired sample t test, SPSS 25.0) (Table 3), which means that the age of seeds was not effective on these parameters.

Table 3. Comparison of germination characteristics of S. crassa seeds from 2013 and 2014.

\begin{tabular}{|c|c|c|c|c|c|c|c|}
\hline & Years & $\begin{array}{l}\text { Number of } \\
\text { samples }\end{array}$ & Mean & $\begin{array}{l}\text { Std } \\
\text { Deviation }\end{array}$ & Sd & t value & $P$ value \\
\hline \multirow{2}{*}{$\begin{array}{l}\text { Germination } \\
\text { percentage }\end{array}$} & 2013 & 13 & 37.08 & 21.26 & \multirow[t]{2}{*}{12} & \multirow[t]{2}{*}{-2.54} & \multirow[t]{2}{*}{0.026} \\
\hline & 2014 & 13 & 49.77 & 35.74 & & & \\
\hline \multirow{2}{*}{$\begin{array}{l}\text { Germination } \\
\text { rate }\end{array}$} & 2013 & 13 & 11.05 & 7.45 & \multirow[t]{2}{*}{12} & \multirow[t]{2}{*}{-3.38} & \multirow[t]{2}{*}{0.005} \\
\hline & 2014 & 13 & 17.40 & 13.08 & & & \\
\hline \multirow{2}{*}{$\begin{array}{l}\text { Recovery } \\
\text { percentage }\end{array}$} & 2013 & 13 & 66.93 & 22.57 & \multirow[t]{2}{*}{12} & \multirow[t]{2}{*}{2.31} & \multirow[t]{2}{*}{0.039} \\
\hline & 2014 & 13 & 56.14 & 21.20 & & & \\
\hline \multirow{2}{*}{$\begin{array}{l}\text { Last } \\
\text { Germination }\end{array}$} & 2013 & 13 & 80.92 & 11.59 & \multirow[t]{2}{*}{12} & \multirow[t]{2}{*}{0.27} & \multirow[t]{2}{*}{0.789} \\
\hline & 2014 & 13 & 80.00 & 16.43 & & & \\
\hline \multirow[t]{2}{*}{ Seed viability } & 2013 & 13 & 88.77 & 9.28 & \multirow[t]{2}{*}{12} & \multirow[t]{2}{*}{2.16} & \multirow[t]{2}{*}{0.051} \\
\hline & 2014 & 13 & 81.38 & 15.10 & & & \\
\hline
\end{tabular}

Seeds stayed non-germinated at the end of the salinity trials first taken into recovery and if they did not germinate, then the viability test was conducted. The color change observed in Figure 5 was an indicator of the viability (Baskin CC \& Baskin JM 1998). According to the classification used by Moore (1972), Delouche (1976) and Grabe (1976); if embryos became entirely light pink or bright red colored, and there was an absence of milky white/yellowish staining at the end of the radicle, then they were considered as viable seed, on the other hand, if embryos were fully colored with crimson red/red-intense or milky white/yellowish and discolored or red-intense radicle end, then they were considered as non-viable seeds (Melo et al. 2020).

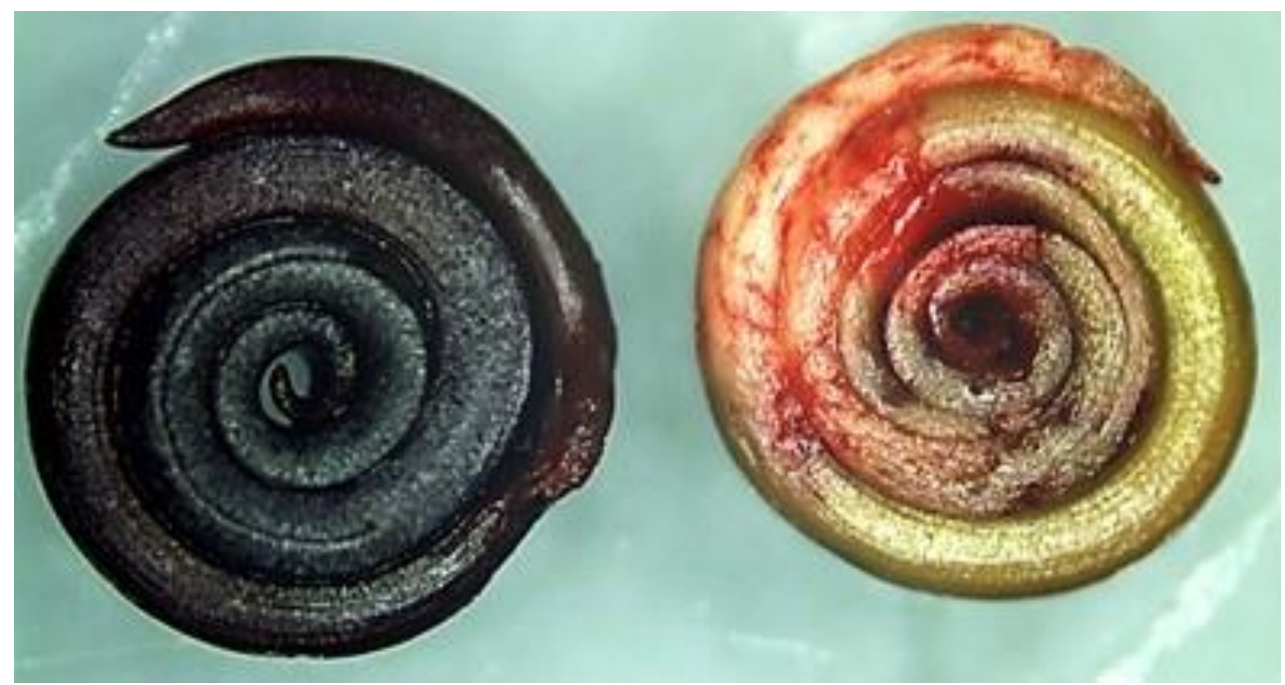

Figure 5. Viable seed (left) and Nonviable seed (right) after the TTC test. 
As stated in the study by De Guzman et al. (2011), the differences between viable and non-viable seeds after the TTC treatment were classified as follows: the seeds were considered as germinable if the embryo completely stained or there were minor unstained areas in the plumule, and were considered as non-germinable if more than the extreme tip of radicle was unstained, more than half the radicle was unstained, the whole radicle unstained plus juncture of the plumule and radicle axis, the whole radicle and half the plumule unstained, radicle and more than half the plumule unstained and greenish in color or the embryo was completely unstained.

As a result, it can be concluded that Salsola crassa is a euhalophyte with seeds that showed better germination under photoperiodism of 12 hours rather than complete dark applications and even though germination rates decreased as other halophytes with increasing salinity, the seeds could even germinate at $1800 \mathrm{mM} \mathrm{NaCl}$. According to the values given in Tables 1 and 2, seed age is an especially important parameter and even being 1-year older results in loss of viability and lack of survival ability.

As a result of this study, it can be concluded that even 2 years of storage influenced the seed viability and decreased the viability about $20 \%$. But to find out the influence of storage period and age of seeds on germination, seeds with different and longer storage periods should be used and in this detailed study, the ROS, ABA, and GA concentrations of seeds should also be determined. Also, the salinity tolerance of seeds has changed with the storage period, but the mechanism or the reasons for this change cannot be explained by the experimental trials conducted.

\section{ACKNOWLEDGEMENTS}

The authors would like to thank to Dr. İsa Başköse and Dr. Mehmet Borga Ergönül for their kind help.

\section{AUTHOR CONTRIBUTION STATEMENT}

The authors confirm contribution to the manuscript as follows; study conception and design: Ahmet Emre Yaprak, Gül Nilhan Tuğ, data collection: İnci Bahar Çınar, Gül Ayyıldız, analysis and interpretation of results, and draft manuscript preparation: İnci Bahar Çınar, Ahmet Emre Yaprak, Gül Nilhan Tuğ, Gül Ayyıldız. All authors reviewed the results and approved the final version of the manuscript.

\section{NOTE}

This study was presented as a poster at the 1. Ulusal Bitki Biyoloji Kongresi, 2-4 Eylül 2015, Bolu, Türkiye (First National Plant Biology Congress in Bolu, Turkey, 2-4 September 2015).

\section{REFERENCES}

Aiazzi, M.T. \& Arguello, J.A. (1992). Dormancy and germination studies on dispersal units of Atriplex cordobensis Gandoger \& Stucker (Chenopodiaceae). Seed Science \& Technology 20(3): 401-407. 
Assaeed, A. (2001). Effect of temperature and water potential on germination of Salsola villosa Del. ex. Roem. Et Schult. Assiut Journal of Agricultural Science 32(2): 173-183.

Atia, A., Debez, A., Barhoumi, Z., Smaoui, A. \& Abdelly, C. (2009). ABA, GA3, and nitrate may control seed germination of Crithmum maritimum (Apiaceae) under saline conditions. Comptes Rendus Biologies 332(8): 704-710. DOI: https://doi.org/10.1016/ j.crvi.2009.03.009.

Baskin, C.C. \& Baskin, J.M. (1998). Seeds: Ecology, Biogeography and Evolution of Dormancy and Germination. Academic Press, San Diego.

Breen, C.M., Everson, C., \& Rogers, K. (1977). Ecological studies on Sprorobolus virginicus (L.) Kunth with particular reference to salinity and inundation. Hydrobiologia 54(2): 135-140.

Bowers, J.E. (2000). Does Ferocactus wislizeni (Cactaceae) have a between-year seed bank? J Arid Environ 45(3): 197-205. DOI: https://doi.org/10.1006/jare.2000.0642.

Çınar, İ.B., Ayyıldız, G., Yaprak, A.E. \& Tuğ, G.N. (2016). Effect of salinity and light on germination of Salsola grandis Freitag, Vural \& N.Adıüzzel (Chenopodiaceae). Commun. Fac. Sci. Univ. Ank. Series C 25(1-2): 25-32.

De la Barrera, E. \& Nobel, P.S. (2003). Physiological ecology of seed germination for the columnar cactus Stenocereus queretaroensis. J Arid Environ 53(3): 297-306. DOI: https://doi.org/10.1006/jare.2002.1050.

Delouche, J.C. (1976). Standardization of vigor tests. Journal of Seed Technology 1(2): 75-85.

De Guzman, L.E.P., Zamora, O.B., Borromeo, T.H., Sta Cruz, P. C. \& Mendoza, T. (2011). Seed Viability and Vigor Testing of Jatropha curcas L. Philippine Journal of Crop Science 36(3): 10-18.

Dietert, M.F. \& Shontz, J.P. (1978). Germination ecology of a Maryland population of saltmarsh bulrush (Scirpus robustus). Estuaries 1(3): 164-170. DOI: https://doi.org/ $10.2307 / 1351458$.

El-Keblawy, A., Al-Ansari, F., Hassan, N. \& Al-Shamsi, N. (2007). Salinity, temperature and light affect germination of Salsola imbricata. Seed Science and Technology 35(2): 272-281. DOI: https://doi.org/10.15258/sst.2007.35.2.03.

Estrelles, E., Biondi, E., Galiè, M., Mainardi, F., Hurtado, A. \& Soriano, P. (2015). Aridity level, rainfall pattern and soil features as key factors in germination strategies in saltaffected plant communities. J Arid Environ 117: 1-9. DOI: https://doi.org/10.1016/ j.jaridenv.2015.02.005.

Flores, J., Arredondo, A. \& Jurado, E. (2005). Comparative seed germination in species of Turbinicarpus: an endangered cacti genus. Natural Areas Journal 25(2): 183-187.

França-Neto, J. \& Krzyzanowski, F. (2019). Tetrazolium: an important test for physiological seed quality evaluation. Journal of Seed Science. 41(3): 359-366. DOI: 10.1590/2317$1545 v 41 n 3223104$.

Gomes, M.P. \& Garcia, Q.S. (2013). Reactive oxygen species and seed germination. Biologia 68(3): 351-357. DOI: 10.2478/s11756-013-0161-y. 
Grabe, D.F. (1970). Tetrazolium Testing Handbook for Agricultural Seeds. Association of Official Seed Analysts, Michigan.

Grabe, D.F. (1976). Manual do Teste de Tetrazólio em Sementes. DF AGIPLAN, Brasília.

Greenway, H. \& Munns, R. (1980). Mechanisms of salt tolerance in nonhalophytes. Ann Rev Plant Physiol 31: 149-90. DOI: https://doi.org/10.1146/annurev.pp.31.060180.001053.

Gul, B., Ansari, R., Flowers, T.J. \& Khan, M.A. (2013). Germination strategies of halophyte seeds under salinity. Environ Exp Bot 92: 4-18. DOI: https://doi.org/10.1016/ j.envexpbot.2012.11.006.

Gul, B. \& Weber, D.J. (1999). Effect of salinity, light, and temperature on germination in Allenrolfea occidentalis. Can J Bot 77(2): 240-246. DOI: https://doi.org/10.1139/b98204.

Guma, I.R., Padrón-Mederos, M.A., Santos-Guerra, A. \& Reyes-Betancort, J.A. (2010). Effect of temperature and salinity on germination of Salsola vermiculata L. (Chenopodiaceae) from Canary Islands. J Arid Environ 74(6): 708-711. DOI: https://doi.org/10.1016/j.jaridenv.2009.10.001.

Huiskes, A.H.L., Stienstra, A.W., Koutstaal, B.P., Markusse, M.M. \& Van Soelen, J. (1985). Germination ecology of Salicornia dolichostachya and S. brachystacya. Acta Bot Neerl 34(4): 369-380. DOI: https://doi.org/10.1111/j.1438-8677.1985.tb01943.x.

Khan, M.A. \& Ungar, I.A. (1984). The effect of salinity and temperature on germination of polymorphic seeds and growth of Atriplex triangularis Wild. Am J Bot 71(4): 481-489. DOI: https://doi.org/10.1002/j.1537-2197.1984.tb12533.x.

Khan, M.A. \& Ungar, I.A. (1997). Effects of thermoperiod on recovery of seed germination of halophytes from saline conditions. Am J Bot 84(2): 279-283. DOI: https://doi.org/ $10.2307 / 2446089$.

Khan, M.A. \& Gul, B. (1998). High salt tolerance in germinating dimorphic seeds of Arthrocnemum indicum. International Journal of Plant Sciences 159(5): 826-832. DOI: https://doi.org/10.1086/297603.

Khan, M.A., Gul, B. \& Weber, D.J. (2002). Seed germination in the Great Basin halophyte Salsola iberica. Can J Bot 80(6): 650-655. DOI: https://doi.org/10.1139/b02-046.

Khan, M.A., Gul, B. \& Weber, D.J. (2004). Temperature and high salinity effects in germinating dimorphic seeds of Atriplex rosea. Western North American Naturalist 164(2): 193-201.

Mandujano, M.C., Golubov, J. \& Montaña, C. (1997). Dormancy and endozoochorous dispersal of Opuntia rastrera seeds in the southern Chihuahuan Desert. J Arid Environ 36(2): 259-266. DOI: https://doi.org/10.1006/jare.1996.0210.

Mandujano, M.C., Montaña, C. \& Rojas-Aréchiga, M. (2005). Breaking seed dormancy in Opuntia rastrera from the Chihuahuan desert. $J$ Arid Environ 62(1): 15-21. DOI: https://doi.org/10.1016/j.jaridenv.2004.10.009.

Mariko, S., Kachi, N., Ishikawa, S. \& Furukawa, A. (1992). Germination ecology of coastal plants in relation to salt environment. Ecological Research 7(3): 225-233. DOI: https://doi.org/10.1007/BF02347091. 
Mehrun-Nisa, Khan, M.A. \& Weber, D.J. (2007). Dormancy, germination and viability of Salsola imbricata seeds in relation to light, temperature and salinity. Seed Science and Technology 35(3): 595-606. DOI: https://doi.org/10.15258/sst.2007.35.3.07.

Melo, L.D.F.A., Junior, J.L.A.M., Ferreira, V.M. \& Neto, J.C.A. (2020). Viability Mimosa bimucronata (DC.) O. Kuntze. seeds by the tetrazolium test and oil content. Diversitas Journal 5(3): 1575-1587. DOI: https://doi.org/10.17648/diversitas-journal-v5i3-846.

Mohammad, S. \& Sen, D.N. (1990). Germination behaviour of some halophytes in Indian desert. Ind J Exp Biol 28(5): 545-549.

Moore, R.P. (1972). Interpretation of color differences in tetrazolium testing. Seed Technologist News 4(3): 22-24.

Onnis, A. \& Bellettato, R. (1972). Dormienza e alotolleranza in due specie spontanee di Hordeum (H. murinum L. e H. marinum Huds). Giornale Botanico Italiano 106(2): 101-113. DOI: https://doi.org/10.1080/11263507209426542

Parsons R.F. (2012). Incidence and ecology of very fast germination. Seed Science Research 22(3): 161-167. DOI: https://doi.org/10.1017/S0960258512000037.

Rasheed, A., Ahmed, M.Z., Gul, B., Khan, M.A. \& Hameed, A. (2019). [Comparative Seed Germination Ecology of Sabkha and Playa Halophytes of Pakistan] In: Gul, B., Böer, B., Khan, M., Clüsener-Godt, M. \& Hameed A. (Eds.). Sabkha Ecosystems. Tasks for Vegetation Science. Vol. 49. Springer, Cham, pp. 41-54. DOI: https://doi.org/10.1007/978-3-030-04417-6_4.

Rees, M. \& Long, M.J. (1993). The analysis and interpretation of seedling recruitment curves. Am Nat 141(2): 233-262. DOI: https://doi.org/10.1086/285471.

Rojas-Aréchiga, M. \& Vázquea-Yanes, C. (2000). Cactus seed germination: a review. J Arid Envirin 44(1): 85-104. DOI: https://doi.org/10.1006/jare.1999.0582.

Rojas-Aréchiga, M., Casas, A. \& Vázquez-Yanes, C. (2001). Seed germination of wild and cultivated Stenocereus stellatus (Cactaceae) from the Tehuacán-Cuicatlán Valley, Central México. J Arid Environ 49(2): 279-287. DOI: https://doi.org/10.1006/jare.2001.0789.

Ruedas, M., Valverde, T. \& Castillo-Argüero, S. (2000). Respuesta germinativa y crecimiento temprano de plántulas de Mammillaria magnimamma (Cactaceae) bajo diferentes condiciones ambientales. Botanical Sciences 66: 25-35. DOI: https://doi.org/10.17129/ botsci. 1608

Sekmen, A.H., Özdemir, F. \& Türkan, İ. (2004). Effects of salinity, light and temperature on seed germination in a Turkish endangered halophyte, Kalidiopsis wagenitzii (Chenopodiaceae). Israel Journal of Plant Sciences 52(1): 21-30. DOI: https://doi.org/ 10.1560/NXAR-71FB-CND5-E8FJ.

Seneca, E.D. (1969). Germination response to temperature and salinity of four dune grasses from the outer banks of North Carolina. Ecology 50(1): 45-53. DOI: https://doi.org/ $10.2307 / 1934661$.

Shimomura, T., Kondo, T. \& Fukai, S. (2000). Breaking seed dormancy of Notocactus submammulosus var. pampeanus (Cactaceae) by Benzyl Adenine and Hydrogen Peroxide (in Japanese). Japan Journal of Agricultural Education 31(1): 21-27.

Soriano, P., Moruno, F., Boscaiu, M., Vicente, O., Hurdato, A., Llinares, J.V. \& Estrelles, E. (2014). Is salinity the main ecologic factor that shapes the distribution of two 
endemic Mediterranean plant species of the genus Gypsophila? Plant Soil 384(1-2): 363-379. DOI: https://doi.org/10.1007/s11104-014-2218-2.

Takeno, K. \& Yamaguchi, H. (1991). Diversity in seed germination behaviour in relation to heterocarpy in Salsola komarovii Iljin. Bot Mag Tokyo 104: 207-215. DOI: https:// doi.org/10.1007/BF02489453.

Terzi, H., Yıldız, M. \& Altuğ, Ü. (2017). Halofit Salsola crassa tohum çimlenmesi üzerine tuzluluk, sıcaklık ve ışığın etkileri. Afyon Kocatepe Üniversitesi Fen ve Mühendislik Bilimleri Dergisi 17: 1-9. DOI: https://doi.org/10.5578/fmbd.52763.

Tielbörger, K. \& Valleriani, A. (2005). Can seeds predict their future? Germination strategies of density-regulated desert annuals. OIKOS 111(2): 235-244. DOI: https://doi.org/ 10.1111/j.0030-1299.2005.14041.x.

Ungar, I.A. (1978). Halophyte seed germination. Bot Rev 44(2): 233-264. DOI: https:// doi.org/10.1007/BF02919080.

Ungar, I.A. (1982). [Germination ecology of halophytes] In: Sen, D.N. \& Rajpurohit, K.S. (Eds.). Contributions to The Ecology of Halophytes. Tasks for Vegetation Science. Vol. 2. Springer, Dordrecht, pp. 143-154. DOI: https://doi.org/10.1007/978-94-0098037-2_10.

Ungar, I.A. (1995). [Seed germination and seed bank ecology in halophytes] In: Kigel, J. \& Galili, G. (Eds.). Seed Development and Seed Germination. Routledge, Boca Raton, pp. 599-628. DOI: https://doi.org/10.1201/9780203740071-23.

Wang, L., Huang, Z., Baskin, C.C., Baskin, J.M. \& Dong, M. (2008). Germination of dimorphic seeds of desert annual halophyte Suaeda aralocaspica (Chenopodiaceae), a C4 plant without Kranz anatomy. Ann Bot 102(5): 757-769. DOI: https://doi.org/ $10.1093 / \mathrm{aob} / \mathrm{mcn} 158$.

Wang, Y., Jiang, G.Q., Han, Y.N. \& Liu, M.M. (2013). Effects of salt, alkali and salt-alkali mixed stresses on seed germination of the halophyte Salsola ferganica (Chenopodiaceae). Acta Ecologica Sinica 33(6): 354-360. DOI: https://doi.org/ 10.1016/j.chnaes.2013.09. 010.

Wei, Y., Dong, M., Huang, Z.Y. \& Tan, D.Y. (2008). Factors influencing seed germination of Salsola affinis (Chenopodiaceae), a dominant annual halophyte inhabiting the deserts of Xinjiang, China. Flora 203(2): 134-140. DOI: https://doi.org/10.1016/j.flora.2007.02. 003.

Williams, S. (2001). Reduced Genetic Diversity in Eelgrass Transplantations Affects both Population Growth and Individual Fitness. Ecol Appl 11(5): 1472-1488. DOI: https://doi.org/10.1890/1051-0761(2001)011[1472:RGDIET]2.0.CO;2.

Woodell, S.R.J. (1985). Salinity and seed germination patterns in coastal plants. Vegetatio. 61(1/3): 223-229. DOI: https://doi.org/10.1007/BF00039828.

Yıldıztugay, E., Özfidan-Konakçı, C. \& Küçüködük, M. (2014). The role of antioxidant responses on the tolerance range of extreme halophyte Salsola crassa grown under toxic salt concentrations. Ecotoxicology and Environmental Safety 110: 21-30. DOI: https:// doi.org/10.1016/j.ecoenv.2014.08.013. 
Yuan, K., Rashotte, A.M. \& Wysocka-Diller, J.W. (2011). ABA and GA signaling pathways interact and regulate seed germination and seedling development under salt stress. Acta Physiol Plant 33: 261-271. DOI: https://doi.org/10.1007/s11738-010-0542-6.

Zhang, H., Zhang, G., Lü, X., Zhou, D. \& Han, X. (2015). Salt tolerance during seed germination and early seedling stages of 12 halophytes. Plant and Soil 388(1-2): 229-241. DOI: https://doi.org/10.1007/s11104-014-2322-3. 